\title{
Expression of CYP1A1, CYP1B1 and MnSOD in a panel of human cancer cell lines
}

\author{
Hanna Piotrowska • Malgorzata Kucinska • \\ Marek Murias
}

Received: 2 June 2013/Accepted: 10 July 2013/Published online: 20 July 2013

(C) The Author(s) 2013. This article is published with open access at Springerlink.com

\begin{abstract}
The expression of P450 enzymes and antioxidative enzymes in tumour tissue can have a major impact on the responsiveness of tumours to cancer chemotherapeutic drugs, therefore such information may be very precious when experiments are designed. The compressive information, concerning the expression of drug metabolism enzymes or antioxidative enzymes is still lacking, therefore in this study the expression of CYP1A1, CYP1B1 and mitochondrial superoxide dismutase MnSOD (both mRNA and protein) in a panel of eight commonly used cancer cell lines, representing four tumour tissues was assayed. In the study two ovarian cancer cell lines A2780 and SKOV-3, two colorectal cancer LOVO and DLD-1, two breast cancer derived MCF-7 and MDA-MB-231 and two cervical cancer cell lines HeLa and C33A were employed. The relatively high expression of all assayed enzymes was shown in MDAMB-231 breast cancer cells, lack of cancer cell specific CYP1B1 protein was discovered in LOVO colorectal cells. In order to test possible correlation between expression of CYP1A1, CYP1B1 and MnSOD and modulators of their activity, cytotoxicity of resveratrol and its promising hydroxylated analogue $3,3^{\prime}, 4,4^{\prime}, 5,5^{\prime}$-trans-hexahydroxystilbene against cell lines used in experiment was assayed. The relatively high correlation was found between $\mathrm{IC}_{50}$
\end{abstract}

Hanna Piotrowska and Malgorzata Kucinska have contributed equally to this study.

Electronic supplementary material The online version of this article (doi:10.1007/s11010-013-1758-8) contains supplementary material, which is available to authorized users.

H. Piotrowska $\cdot$ M. Kucinska $\cdot$ M. Murias $(\bowtie)$

Department of Toxicology, Poznan University of Medical

Sciences, ul. Dojazd 30, 60-631 Poznan, Poland

e-mail: marek.murias@ump.edu.pl values calculated for $3,3^{\prime}, 4,4^{\prime}, 5,5^{\prime}$-trans-hexahydroxystilbene and expression of MnSOD ( $r=0.6562)$.

Keywords CYP1A1 - CYP1B1 - Mitochondrial superoxide dismutase $\cdot$ Human cancer cell line

\begin{tabular}{|c|c|}
\hline \multicolumn{2}{|l|}{ Abbreviations } \\
\hline A 2780 & Human ovarian carcinoma cell line \\
\hline AP-1 & Activator protein 1 \\
\hline ATCC & American Type Culture Collection \\
\hline C33A & Human cervical carcinoma \\
\hline CYP & Cytochrome P450 \\
\hline DLD-1 & $\begin{array}{l}\text { Human colon adenocarcinoma cell } \\
\text { line }\end{array}$ \\
\hline DMEM & Dulbecco's modified Eagle medium \\
\hline ECACC & European Collection of Cell Cultures \\
\hline FBS & Foetal bovine seum \\
\hline GAPDH & $\begin{array}{l}\text { Glyceraldehyde 3-phosphate } \\
\text { dehydrogenase }\end{array}$ \\
\hline HeLa & $\begin{array}{l}\text { Human cervix epitheloid carcinoma } \\
\text { cell line }\end{array}$ \\
\hline HRP & Horseradish peroxidase \\
\hline LoVo & $\begin{array}{l}\text { Human colon adenocarcinoma cell } \\
\text { line }\end{array}$ \\
\hline M-MVL & Moloney murine leukaemia virus \\
\hline M12 & $\begin{array}{l}3,3^{\prime}, 4,4^{\prime}, 5,5^{\prime} \text {-trans- } \\
\text { Hexahydroxystilbene }\end{array}$ \\
\hline $\mathrm{MCF}-7$ & $\begin{array}{l}\text { Human Caucasian breast } \\
\text { adenocarcinoma }\end{array}$ \\
\hline MDA-MB-231 & $\begin{array}{l}\text { Human Caucasian breast } \\
\text { adenocarcinoma }\end{array}$ \\
\hline MnSOD & Mitochondrial superoxide dismutase \\
\hline MRPL19 & Mitochondrial ribosomal protein L19 \\
\hline OD & Optical density \\
\hline OVCAR-3 & Human ovarian carcinoma cell line \\
\hline
\end{tabular}


PAHs

RA

RQ-PCR

SDS

SKOV-3

CuZnSOD (SOD1)

MnSOD (SOD2)

SOD3

\section{Introduction}

A cancer cell culture has been used as a valuable tool for discovery and development of new anticancer drugs for decades. They are used for academic, clinical and industrial research. Although, the most commonly used cell lines were applied in experiments described in thousands of papers, even the most important cell culture collections do not provide compressive information describing their biological properties like, e.g. the expression of drug metabolizing enzymes, drug transporters, receptors or antioxidative enzymes. Only few experimental papers describing and comparing the expression and/or activity of crucial for cancer cell enzymes and factors have been published so far, e.g. in a panel of cancer cell lines activity of P450 enzyme was described by $\mathrm{Yu}$ et al. [1], microRNA expression profiles were presented by Blower et al. [2], global microRNA analysis was performed by Solkilde et al. [3], while expression of nuclear receptors was described by Holbeck et al. [4]. Compresive analysis of p53 status in cancer cell lines was provided by Berglind et al. [5] using UMD_p53 database available on http://p53.free.fr.

Since the expression of P450 enzymes and antioxidative enzymes in tumour tissue can have a major impact on the responsiveness of tumours to cancer chemotherapeutic drugs, such information may be very precious when experiments are designed. Information regarding expression of key drug metabolizing enzymes and antioxidative enzymes may be also useful when prodrugs activated by cellular metabolic systems are prepared [6-9].

P450 cytochromes are enzymes which catalyse Phase-I metabolism reactions. These family haem-containing enzymes catalyse $\mathrm{C}-, \mathrm{N}$ - and $\mathrm{S}$-oxidation and dealkylation reactions of both xenobiotics and endobiotics. P450 1A1 (CYP1A1) is, from a pharmacological point of view, one of the most important members of the CYP family. CYP1A1 participates in the metabolism of a large number of xenobiotics, as well as a small number of endogenous substrates. CYP1A1 is responsible for the metabolism of various drugs, food components, and environmental contaminants. At the same time hydroxylation at a vacant position of an aromatic ring belongs to the most important reactions catalysed by this enzyme. This reaction is believed to be a critical step for the initiation of carcinogenesis, through the formation of highly reactive conversion products that can cause oncogenic and teratogenic mutations in experimental animals and humans $[10,11]$.

Another interesting member of the CYP1 subfamily is P450 1B1 (CYP1B1) cytochrome which is, similarly to CYP1A1, involved in the metabolism of xenobiotics and endobiotics. Similarly to CYP1A1, CYP1B1 activates several environmental mutagens, e.g. polycyclic aromatic hydrocarbons (PAHs), heterocyclic amines and aromatic amines [6]. CYP1B1 also catalyses the 4-hydroxylation of estrogens considered to be an important step in hormonal carcinogenesis [6]. Human CYP1B1 protein was detected in a variety of tumours but could not be detected in adjacent to normal tissues, where only mRNA was detected. This suggests that CYP1B1 could activate anticancer agents specifically in the cancer cells. The range of therapeutic strategies including CYP1B1-activated prodrugs as well as CYP1B1 inhibitors are currently tested [8].

The redox cycling of polyhydroxylated compounds catalysed by CYP1A1 and CYP1B 1 may result in generation of superoxide radicals. Superoxide radical $\left(\mathrm{O}_{2}{ }^{-}\right)$plays a central role in oxidative stress and impacts on the production of a plethora of other reactive oxygen species. The cellular and extracellular level of $\mathrm{O}_{2}{ }^{-}$is therefore controlled by the family of very efficient enzymes belonging to the superoxide dismutase (SOD) family. Cu, ZnSOD (SOD1) is located in cytosol, MnSOD (SOD2) is located in the mitochondrial matrix, while SOD3 is located in extracellular space $[12,13]$. These enzymes catalyse the dismutation (disproportionation) of $\mathrm{O}_{2}{ }^{--}$to hydrogen peroxide and molecular oxygen and are essential to protect aerobic life from the toxic effects of oxygen $[12,13]$. Some studies reported that MnSOD expression is elevated in cancer cells compared to normal tissue, including gastric and oesophageal [14, 15], colorectal [16], prostate [17] and lung cancer [18]. Moreover, MnSOD was shown in several reports to exert significant effect on growth and survival of cancer cells, for instance, changes in MnSOD levels in the cell affect the transcriptional activity of activator protein-1 (AP-1), dramatically increasing cells proliferation $[19,20]$. It was reported by some authors that MnSOD overexpression may suprese tumour growth [21]; on the other hand, significant association between increased MnSOD activity and poor prognosis in cancer can be attributed to alterations in cancer cell migratory and invasive capacity [22]. Some reports describe MnSOD-p53 interactions [23-30]. Our own results suggest that ROS-generating agents may cause p53-mediated MnSOD downregulation and lead to induction of p53-transcriptional functions, which subsequently lead to the activation of mitochondrial driven apoptotic processes. MnSOD is therefore believed a key enzyme involved in the establishment of the cellular redox environment and controlling the biological status of cells. 
Inhibition of CYP1 isoenzymes by resveratrol and methoxy- hydroxy- as well as thiomethylstilbenes was shown in several in vitro models [31-37]. This project is kind of pre-study preceding broader project aiming to evaluate relationship between CYP1A1, CYP1B1 and MnSOD and their effect on cytotoxic activity of resveratrol and its higher hydroxylated analogues. Therefore, as a first step we needed to screen expression of these enzymes in a panel of cancer cells and find possible correlation between their expression and cytotoxicity.

\section{Materials and methods}

Chemicals

Resveratrol analogue 3,3',4,4',5,5'-trans-hexahydroxystilbene (M12), was synthesized as described previously [38]. The RQ-PCR probes were provided by Roche (Mannheim, Germany). Probe numbers: 59, 61, 27, 60 and 23 were used for CYP1A1, CYP1B1, MnSOD, GADPH, and MRPL19 detection, respectively. The monoclonal antibodies were purchased from Santa Cruz Biotechnology (Dallas, TX USA). All other reagents used in experiments (including resveratrol) were purchased from Sigma-Aldrich (St. Louis, MO, USA).

\section{Cell culture}

The cancer cell lines used in the experiment were purchased from the European Type Culture Collection (Sigma-Aldrich Co., St. Louis, MO, USA). The cell lines are listed in Table 1. The cells were maintained in phenol red-free DMEM medium supplemented with $10 \%$ foetal bovine serum (FBS), $2 \mathrm{mM}$ glutamine, penicillin (100 U/ $\mathrm{ml})$, and streptomycin $(0.1 \mathrm{mg} / \mathrm{ml})$. The cells were cultivated under standard conditions at $37{ }^{\circ} \mathrm{C}$ in a humidified atmosphere containing $5 \% \mathrm{CO}_{2}$ and $95 \%$ air. For RNA isolation and western blot analysis the cells were seeded in a 6-well plates at a density of $1 \times 10^{6}$ cells per well. All the cell culture chemicals were obtained from SigmaAldrich Co. St. Louis, MO, while all the cell culture consumables were provided by BD Falcon.

\section{Real-time quantitative PCR (RTq-PCR) analysis}

Total RNA was isolated according to the method of Chomczynski and Sacchi [39].The RNA concentration was quantified by measuring the optical density (OD) at $260 \mathrm{~nm}$ and their integrity was confirmed by denaturing agarose gel electrophoresis. RNA samples were treated with DNAse I and reverse-transcribed into cDNA using oligo-dT primers. Reverse transcription was performed using M-MLV Reverse Transcriptase (Invitrogen, Carlsbad, CA, USA) according to manufacturer instructions.

RQ-PCR was conducted in the Light Cycler real-time PCR detection system Roche Diagnostics GmbH, (Mannheim, Germany) using a LightCycler ${ }^{\circledR} 480$ Probes Master kit. Target cDNA was quantified using the relative quantification method. The quantity of CYP1A1, CYP1B1 and MnSOD in each sample was standardized by GAPDH and MRPL19 (Table 2). For RTq-PCR analysis of CYP1A1, CYP1B1 and MnSOD mRNA expression, $1 \mu$ l of total $(20 \mu \mathrm{l})$ cDNA solution was added to the mixture of the LightCycler $^{\circledR} 480$ Probes Master kit (Roche, Mannheim, Germany), primers and probes for CYP1A1, CYP1B1 and MnSOD respectively. In case of negative control, cDNA was not added.

\section{SDS-PAGE and western blot analysis}

The cells were grown in 6 well plates. The cells were collected when they were $60 \%$ confluent and dissolved in a RIPA buffer with proteinase inhibitors (30 min on ice) and centrifuged. The obtained supernatant was used for electrophoresis, protein concentration in supernatant was determined using Qubit fluorometer (Invitrogen) and Quant-iTTM Protein Assay Kit (Invitrogen, Burlington, Ontario,Canada). For electrophoresis, $30 \mu \mathrm{g}$ of protein were resuspended in sample buffer and separated on $10 \%$ Tris-glycine gel using SDS-PAGE. Gel proteins were transferred to nitrocellulose, which was blocked with $5 \%$ milk in Tris buffered saline/Tween. Immunodetection was performed with rabbit polyclonal anti-CYP1A1 Ab (sc20772), rabbit polyclonal anti-CYP1B1 Ab (sc-32882), anti-MnSOD Ab (sc-30080) followed by incubation with goat anti-rabbit HRP- conjugated Ab (sc-2004). The membranes were also incubated with anti-actin HRP conjugated $\mathrm{Ab}$ (sc-1616) to ensure equal protein loading of the lanes. Bands were revealed using SuperSignal West Femto maximum sensitivity substrate Pierce Biotechnology Inc. (Rockford, IL, USA). Densitometric quantification of band intensity was measured using ImageJ 1.46 software (NIH, USA) and was normalised relatively to the band intensity of the $\beta$-actin loading control.

\section{Cytotoxicity study}

As recent data showed the MTT-reducing activity can be increased by the polyphenolic antioxidant resveratrol without a corresponding increase in the number of living cells, therefore a protein determination assay was used for the cytotoxicity experiments adapted from Seibert et al. [40]. Briefly, the cells were detached using trypsin, counted using Casy-1 cell counter (Scharfe System, Reutlingen Germany), and seeded into 96 well plates at the density of 
Table 1 Cancer cell lines used in experiment

\begin{tabular}{|c|c|c|c|c|}
\hline Cell line & $\begin{array}{l}\text { Tissue/karyotype (ETCC/ } \\
\text { ATCC description) }\end{array}$ & ETCC/ATCC description & $\begin{array}{l}\text { Morphology/Growth } \\
\text { mode }\end{array}$ & p53 status \\
\hline DLD-1 & $\begin{array}{l}\text { Human colon } \\
\text { adenocarcinoma/2n=46, } \\
\text { pseudodiploid }\end{array}$ & $\begin{array}{l}\text { Derived from human colorectal adenocarcinoma. } \\
\text { The cells have been used in the study of polar } \\
\text { solvents on cell characteristics }\end{array}$ & Epithelial/adherent & Mutated $[49,50]$ \\
\hline LOVO & $\begin{array}{l}\text { Human colon } \\
\text { adenocarcinoma/modal } \\
\text { no. } 49,(2 n=46)\end{array}$ & $\begin{array}{l}\text { Derived from a metastatic tumour in the left } \\
\text { supraclavicular region of a 56-year-old male } \\
\text { with adenocarcinoma of the colon. The cells } \\
\text { produce carcino embryonic antigen (CEA) }\end{array}$ & Epithelial/adherent & Wt [49] \\
\hline A2780 & $\begin{array}{l}\text { Human ovarian carcinoma/ } \\
\text { not specified }\end{array}$ & $\begin{array}{l}\text { The A2780 human ovarian cancer cell line was } \\
\text { established from tumour tissue from an } \\
\text { untreated patient. Cells grow as a monolayer } \\
\text { and in suspension in spinner cultures }\end{array}$ & Epithelial/adherent & Wt [51] \\
\hline SKOV3 & $\begin{array}{l}\text { Human caucasian ovary } \\
\text { adenocarcinoma/ } \\
\text { hypodiploid to } \\
\text { hypotetraploid }\end{array}$ & $\begin{array}{l}\text { Derived from the ascitic fluid from a 64-year-old } \\
\text { Caucasian female with an ovarian tumour. } \\
\text { Forms moderately well-differentiated } \\
\text { adenocarcinoma consistent with ovarian } \\
\text { primary cells }\end{array}$ & Epithelial/adherent & Wt [51] \\
\hline MCF-7 & $\begin{array}{l}\text { Human Caucasian breast } \\
\text { adenocarcinoma } / 2 n=46, \\
\text { hypertriploid to } \\
\text { hypotetraploid }\end{array}$ & $\begin{array}{l}\text { Established from the pleural effusion from a } \\
69 \text {-year-old Caucasian female suffering from a } \\
\text { breast adenocarcinoma. Cells exhibit some } \\
\text { features of differentiated mammary epithelium } \\
\text { including oestradiol synthesis and formation of } \\
\text { domes. Cells may carry B or C type retrovirus } \\
\text { and are considered to represent a category } 2 \\
\text { pathogen (P2 containment). Cells express both } \\
\text { the wild type and variant oestrogen receptors as } \\
\text { well as progesterone receptor }\end{array}$ & Epithelial-like/adherent & Wt [52] \\
\hline $\begin{array}{l}\text { MDA-MB- } \\
231\end{array}$ & $\begin{array}{l}\text { Human caucasian } \\
\text { adenocarcinoma/modal } \\
\text { no.'s } 62 \text { and } 64, \text { near } \\
\text { triploid }\end{array}$ & $\begin{array}{l}\text { Isolated from pleural effusions of a breast cancer } \\
\text { patient }\end{array}$ & Epithelial/adherent & Mutated [53] \\
\hline HeLa & $\begin{array}{l}\text { Human cervix epitheloid } \\
\text { carcinoma/modal no.'s } 62 \\
\text { and } 64, \text { near triploid }\end{array}$ & $\begin{array}{l}\text { Derived from a cervical carcinoma from a } \\
31 \text {-year-old female. This was the first } \\
\text { aneuploid line derived from human tissue } \\
\text { maintained in continuous cell culture. } \\
\text { Susceptible to Poliovirus type I and adenovirus } \\
\text { type 3. Identified as a contaminant in many } \\
\text { other cell lines. The cells should be handled } \\
\text { under laboratory containment level } 2 \text {. } \\
\text { Ethnicity: Black }\end{array}$ & Epithelial/adherent & Wt [54] \\
\hline C-33A & $\begin{array}{l}\text { Human Caucasian cervical } \\
\text { carcinoma/hypodiploid }\end{array}$ & $\begin{array}{l}\text { Derived from a cervical carcinoma from a } \\
66 \text {-year-old female }\end{array}$ & Epithelial/Adherent & $\begin{array}{l}\text { Mutated [55] } \\
\text { 273/CGT > TGT }\end{array}$ \\
\hline
\end{tabular}

10,000 cells $/ 100 \mu \mathrm{L} /$ well. Cells were allowed to attach overnight and incubated for $24 \mathrm{~h}$ with resveratrol and $3,3^{\prime}, 4,4^{\prime}, 5,5^{\prime}$-trans-hexahydroxystilbene in concentrations ranging from 1.5 to $100 \mu \mathrm{M}$ in six replicates. DMSO was used as a control, and the concentration in medium did not exceed $0.1 \%$.Two groups of six wells receiving $0.1 \%$ DMSO served as a control. After incubation, the medium was aspirated and the cell layers were washed three times with phosphate buffered saline (PBS). Cells were lysed by incubation with $0.5 \mathrm{~N} \mathrm{NaOH}$ for $45 \mathrm{~min}$ at $37{ }^{\circ} \mathrm{C}$. Protein content was determined Bio-Rad Protein Assay Kit (Bio-
Rad Hercules, USA) modified for microtiter plates. Bovine serum albumin (BSA) (1.5-24 $\mu \mathrm{g} /$ well) was used to determine the standard curve. Absorption at $750 \mathrm{~nm}$ was read with a microtiter plate photometer (ELX800, BioTEK). The protein content of culture wells was compared to the mean protein content of the control cultures (12wells per plate) and expressed as percentage of control. Experiments were replicated at least 2 times with cultures of different passages. The $\mathrm{IC}_{50}$ values were determined from semilogarithmic plots of the mean concentrationeffect relationships. 
Table 2 Oligonucleotide sequences used for RTq-PCR analysis

\begin{tabular}{|c|c|c|c|c|}
\hline Transcript & Sequence $\left(5^{\prime}-3^{\prime}\right.$ direction $)$ & $\begin{array}{l}\text { Probe } \\
\text { number }\end{array}$ & $\begin{array}{l}\text { Gene accession } \\
\text { number }\end{array}$ & $\begin{array}{l}\text { Product } \\
\text { size }(b p)\end{array}$ \\
\hline CYP1A1 & $\begin{array}{l}5^{\prime} \text { ggggcgttgtgtctttgtaa } 3^{\prime} \\
5^{\prime} \text { tgggttgacccatagcttct } 3^{\prime}\end{array}$ & 59 & NM_000499.3 & 64 \\
\hline CYP1B1 & $\begin{array}{l}5^{\prime} \text { ggcattagagtcaactacacaaagc } 3^{\prime} \\
5^{\prime} \text { gaatggcaagtgccaaaaa } 3^{\prime}\end{array}$ & 61 & NM_000104.3 & 67 \\
\hline SOD-2 & $\begin{array}{l}5^{\prime} \text { gcactagcagcatgttgagc } 3^{\prime} \\
5^{\prime} \text { gagcccagatacccaaaac } 3^{\prime}\end{array}$ & 27 & NM_001024466.1 & 76 \\
\hline GAPDH & $\begin{array}{l}5^{\prime} \text { ctctgctcctcetgttcgac } 3^{\prime} \\
5^{\prime} \text { acgaccaaatccgttgactc } 3^{\prime}\end{array}$ & 60 & NM_002046.3 & 112 \\
\hline MRPL19 & $\begin{array}{l}5^{\prime} \text { caattacacgcgtgaaccac } 3^{\prime} \\
5^{\prime} \text { ggtggagtaggcacattgaaa } 3^{\prime}\end{array}$ & 23 & NM_014763.3 & 62 \\
\hline
\end{tabular}

Statistical analysis

One-way ANOVA followed by Dunnett's multiple comparisons test was performed using GraphPad Prism version 6.02 for Windows, GraphPad Software, La Jolla California USA, www.graphpad.com.

\section{Results}

In this study expression of cytochrome P450 (CYP) isoforms CYP1A1, CYP1B1 as well as MnSOD in 8 cell lines representing 4 tumuor tissues is presented. In the tested cells the highest MnSOD mRNA expression was found in MDA-MB-231 cells $(\mathrm{RA}=1.79 \pm 0.14)$, while the lowest expression was found in MCF-7 $(\mathrm{RA}=0.34 \pm 0.09)$, $\mathrm{C} 33 \mathrm{~A} \quad(\mathrm{RA}=0.32 \pm 0.07) \quad$ and $\mathrm{A} 2780$ $(\mathrm{RA}=0.31 \pm 0.02)$ cell lines. These results were in agreement with MnSOD protein level measured using the western blot technique. The only exception was LOVO cell line. In this colorectal cell line the level of MnSOD protein was relatively high when compared with mRNA (Fig. 1). The highest level of CYP1A1 mRNA was found in both breast cancer cell lines: $\mathrm{MCF}-7(\mathrm{RA}=2.04 \pm 0.43)$ and MDA-MB-231 $(\mathrm{RA}=1.86 \pm 0.30)$ used in our screening; similarly the highest level of CYP1A1 protein was found in these lines (Fig. 2). The most interesting results were obtained for CYP1B1; the highest level of CYP1B1 protein was again measured in HeLa and SKOV-3 cells followed by MDA-MB-231 cells. CYP1B1 mRNA and protein level in LOVO cells can be presented as the most interesting results obtained in our study. The CYP1B1 mRNA level was very low $(\mathrm{RA}=0.05 \pm 0.01)$ while $\mathrm{CYP} 1 \mathrm{~B} 1$ protein was not present in colorectal LOVO cancer cells (Fig. 3). Detailed statistical analysis is provided in supplementary materials (Tables 1s, 2s, 3s).

In order to test possible relationship between the expression of CYP1A1, CYP1B1 and MnSOD and
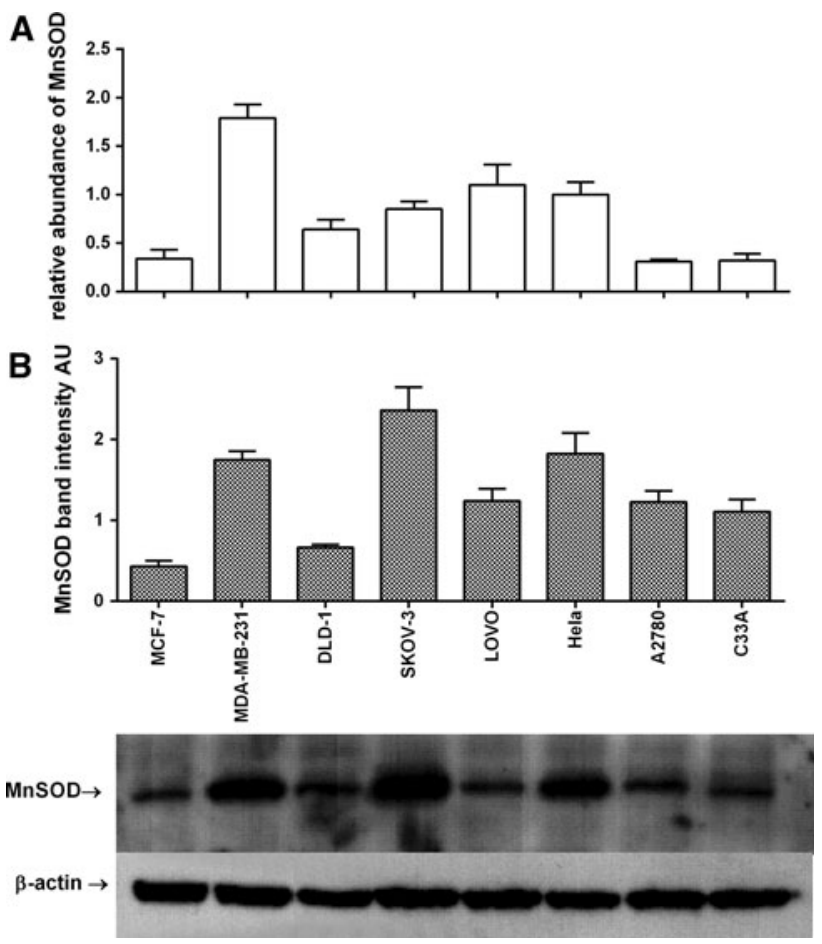

Fig. 1 Gene and protein expression of MnSOD in tested cell lines. A RTq-PCR analyses; relative abundance of MnSOD mRNAs, B Western blot analyses of MnSOD bands, the bands of $\beta$-actin were measured to normalise the results. Densitometric quantification of the corresponding bands was performed using ImageJ 1.45 software. All results are presented and mean \pm SD from three experiments. Detailed statistical analysis is provided in supplementary materials

cytotoxicity of compounds tested in our laboratory we were able to analyse the relationship between cytotoxic activity of resveratrol (3,4',5-trans-hydroxystilbene) and 3,3',4,4',5,5'-trans-hexahydroxystilbene (M12). The $\mathrm{IC}_{50}$ values obtained in cytotoxicity studies are presented in Table 3. The relatively high correlation $\left(r^{2}=0.6562\right)$ between expression of MnSOD and cytotoxicity of M12 was found and presented in Fig. 4, all other relationships are presented in Fig. 1s. 

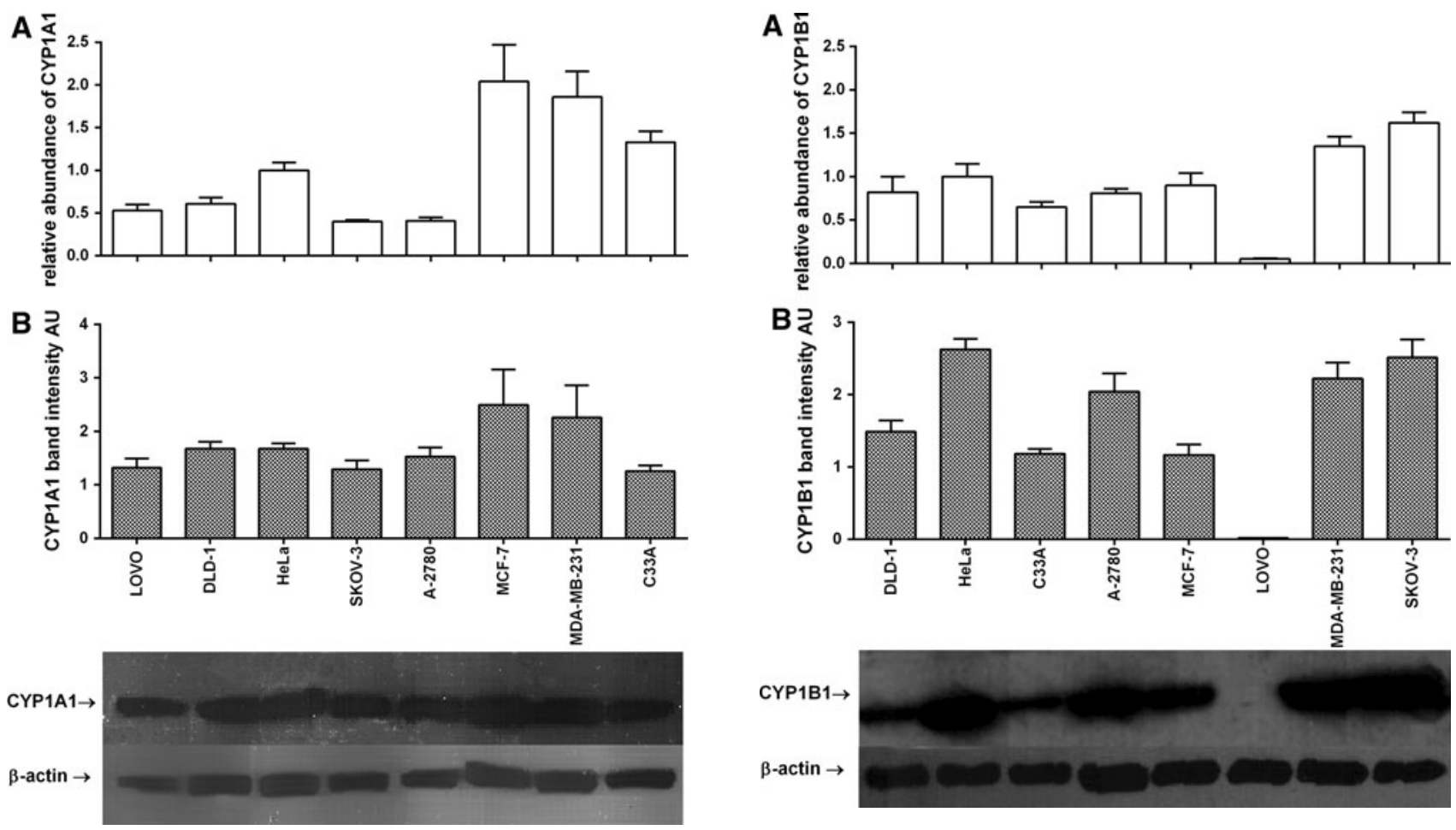

Fig. 2 Gene and protein expression of CYP1A1 in tested cell lines. A RTq-PCR analyses; relative abundance of CYP1A1 mRNAs, B Western blot analyses of CYP1A1 bands, the bands of $\beta$-actin were measured to normalise the results. Densitometric quantification of the corresponding bands was performed using ImageJ 1.45 software. All results are presented and mean \pm SD from three experiments. Detailed statistical analysis is provided in supplementary materials

\section{Discussion}

Cancer cell lines are extensively used for various experiments in scientific laboratories worldwide. Although, a plethora of data is generated every day in the field of cancer cells research, there is a need for systematization and collation of available information about their properties like expression of enzymes, receptors or transcription factors. The expression of drug metabolizing and antioxidative enzymes is a crucial parameter for designing of anticancer drugs [41, 42]. Differences in the expression of drug metabolizing enzymes and drug transporters in cancer cells, were shown in several reports and were used to explain diverse effect of several natural products and anticancer agents against different cancer cell lines. For instance, it was shown that the expression of organic aniontransporting polypeptides 1B1 and 1B3 in ovarian cancer OVCAR-3 and SKOV-3 cells may modulate paclitaxel disposition during therapy [43], while the expression of sulfotransferase 1A1 may modify growth of breast cancer cells incubated with resveratrol [44]. The activation of the natural product eupatorin, which is attributed to CYP1A1 expression in MDA-MB-486 cells, but not normal MCF-

Fig. 3 Gene and protein expression of CYP1B1 in tested cell lines. A RTq-PCR analyses; relative abundance of CYP1B1 mRNAs, B Western blot analyses of CYP1B1 bands, the bands of $\beta$-actin were measured to normalise the results. Densitometric quantification of the corresponding bands was performed using ImageJ 1.45 software. All results are presented and mean $\pm \mathrm{SD}$ from three experiments. Detailed statistical analysis is provided in supplementary materials

Table 3 Cytotoxic activity of resveratrol and M12 against cell lines used in experiment

\begin{tabular}{llr}
\hline Cell line & Resveratrol $\mathrm{IC}_{50}(\mu \mathrm{M})$ & $\mathrm{M}^{2} \mathrm{IC}_{50}(\mu \mathrm{M})$ \\
\hline MCF-7 & $49.7 \pm 9.4$ & $25.6 \pm 6.1$ \\
MDA-MB-231 & $38.1 \pm 5.4$ & $127.8 \pm 1.6$ \\
DLD-1 & $42.7 \pm 1.1$ & $25.3 \pm 2.6$ \\
SKOV-3 & $44.4 \pm 9.8$ & $94.4 \pm 1.5$ \\
LOVO & $57.0 \pm 8.4$ & $36.7 \pm 4.0$ \\
Hela & $53.9 \pm 1.3$ & $35.2 \pm 5.8$ \\
A2780 & $35.4 \pm 2.5$ & $18.4 \pm 0.9$ \\
C33A & $72.5 \pm 4.7$ & $11.6 \pm 2.5$ \\
\hline
\end{tabular}

10A cells, was described by Androutsopoulos and coworkers [45]. It was also suggested that different CYP1B1 expression patterns in ovarian cell lines A2780 and SKOV-3 may affect their sensitivity to cytotoxic activity of 3,4,4',5-tetramethoxystilbene (DMU-212) [46]. In our opinion data presented in this paper may be very helpful in designing similar experiments. On the other hand, this information may be also useful in designing experiments employing transfection of these cells with siRNA or cDNA targeting CYP1A1, CYP1B1 and 


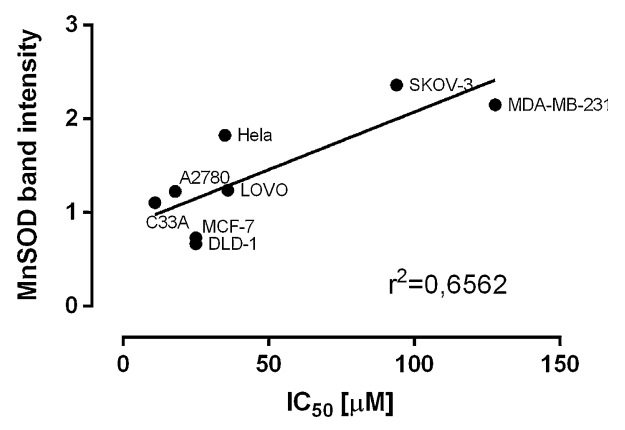

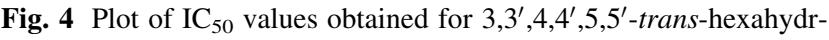
oxystilbene (M12) in cytotoxicity study versus Western blot bands intensities of MnSOD

MnSOD. For example, such experiments were used for explanation of activation of 2-amino-1-methyl-6-phenylimidazo[4,5-b]pyridine by CYP1A1 on mutagenesis and DNA damage in CHO cells [47], while experiments employing CYP1B1 transfected cells were used to explain its role in activation of docetaxel [48]. As it was shown in our cytotoxicity study, the correlations between the P450 or MnSOD activities and the patterns of toxicity of anticancer agents may also aid in the design of further experiments to evaluate new hypotheses regarding the role of P450 and MnSOD enzymes in the metabolism of selected anticancer agents. The most interesting results of our study showed, that level of MnSOD expression in cancer cells may modulate cytotoxic effect exerted by superoxide generating compounds like, e.g. M12, this hypothesis, however, should be further evaluated using cells stably transfected with MnSOD.

Acknowledgments This study was supported by Polish National Science Center by Grant Number N405 180135 (1801/B/P01/2008/35).

Conflict of interest Authors declare that there is no conflict of interest.

Open Access This article is distributed under the terms of the Creative Commons Attribution License which permits any use, distribution, and reproduction in any medium, provided the original author(s) and the source are credited.

\section{References}

1. Yu LJ, Matias J, Scudiero DA, Hite KM, Monks A, Sausville EA, Waxman DJ (2001) P450 enzyme expression patterns in the NCI human tumor cell line panel. Drug Metab Dispos 29:304-312

2. Blower PE, Verducci JS, Lin S, Zhou J, Chung JH, Dai Z, Liu CG, Reinhold W, Lorenzi PL, Kaldjian EP, Croce CM, Weinstein JN, Sadee W (2007) MicroRNA expression profiles for the NCI60 cancer cell panel. Mol Cancer Ther 6:1483-1491

3. Sokilde R, Kaczkowski B, Podolska A, Cirera S, Gorodkin J, Moller S, Litman T (2011) Global microRNA analysis of the NCI-60 cancer cell panel. Mol Cancer Ther 10:375-384
4. Holbeck S, Chang J, Best AM, Bookout AL, Mangelsdorf DJ, Martinez ED (2010) Expression profiling of nuclear receptors in the NCI60 cancer cell panel reveals receptor-drug and receptorgene interactions. Mol Endocrinol 24:1287-1296

5. Berglind H, Pawitan Y, Kato S, Ishioka C, Soussi T (2008) Analysis of p53 mutation status in human cancer cell lines: a paradigm for cell line cross-contamination. Cancer Biol Ther 7:699-708

6. Guengerich F, Chun YJ, Kim D, Gillam EM, Shimada T (2003) Cytochrome P450 1B1: a target for inhibition in anticarcinogenesis strategies. Mutat Res 523-524:173-182

7. Holley AK, Dhar SK, Xu Y, St Clair DK (2012) Manganese superoxide dismutase: beyond life and death. Amino Acids 42:139-158

8. McFadyen MC, Murray GI (2005) Cytochrome P450 1B1: a novel anticancer therapeutic target. Future Oncol 1:259-263

9. Nandekar PP, Sangamwar AT (2012) Cytochrome P450 1A1mediated anticancer drug discovery: in silico findings. Expert Opin Drug Discov 7:771-789

10. Androutsopoulos VP, Tsatsakis AM, Spandidos DA (2009) Cytochrome P450 CYP1A1: wider roles in cancer progression and prevention. BMC Cancer 9:187

11. Stejskalova L, Pavek P (2011) The function of cytochrome P450 1A1 enzyme (CYP1A1) and aryl hydrocarbon receptor (AhR) in the placenta. Curr Pharm Biotechnol 12:715-730

12. Buettner GR (2011) Superoxide dismutase in redox biology: the roles of superoxide and hydrogen peroxide. Anticancer Agents Med Chem 11:341-346

13. Miriyala S, Spasojevic I, Tovmasyan A, Salvemini D, Vujaskovic Z, St CD, Batinic-Haberle I (2012) Manganese superoxide dismutase, MnSOD and its mimics. Biochim Biophys Acta 1822:794-814

14. Izutani R, Kato M, Asano S, Imano M, Ohyanagi H (2002) Expression of manganese superoxide disumutase influences chemosensitivity in esophageal and gastric cancers. Cancer Detect Prev 26:213-221

15. Malafa M, Margenthaler J, Webb B, Neitzel L, Christophersen M (2000) MnSOD expression is increased in metastatic gastric cancer. J Surg Res 88:130-134

16. Toh Y, Kuninaka S, Oshiro T, Ikeda Y, Nakashima H, Baba H, Kohnoe S, Okamura T, Mori M, Sugimachi K (2000) Overexpression of manganese superoxide dismutase mRNA may correlate with aggressiveness in gastric and colorectal adenocarcinomas. Int J Oncol 17:107-112

17. Venkataraman S, Wagner BA, Jiang X, Wang HP, Schafer FQ, Ritchie JM, Patrick BC, Oberley LW, Buettner GR (2004) Overexpression of manganese superoxide dismutase promotes the survival of prostate cancer cells exposed to hyperthermia. Free Radic Res 38:1119-1132

18. Chung-man HJ, Zheng S, Comhair SA, Farver C, Erzurum SC (2001) Differential expression of manganese superoxide dismutase and catalase in lung cancer. Cancer Res 61:8578-8585

19. Kiningham KK, St Clair DK (1997) Overexpression of manganese superoxide dismutase selectively modulates the activity of Jun-associated transcription factors in fibrosarcoma cells. Cancer Res 57:5265-5271

20. Zhao Y, Kiningham KK, Lin SM, St Clair DK (2001) Overexpression of MnSOD protects murine fibrosarcoma cells (FSa-II) from apoptosis and promotes a differentiation program upon treatment with 5-azacytidine: involvement of MAPK and NFkappaB pathways. Antioxid Redox Signal 3:375-386

21. Oberley LW (2005) Mechanism of the tumor suppressive effect of MnSOD overexpression. Biomed Pharmacother 59:143-148

22. Connor KM, Hempel N, Nelson KK, Dabiri G, Gamarra A, Belarmino J, Van De Water L, Mian BM, Melendez JA (2007) 
Manganese superoxide dismutase enhances the invasive and migratory activity of tumor cells. Cancer Res 67:10260-10267

23. Behrend L, Mohr A, Dick T, Zwacka RM (2005) Manganese superoxide dismutase induces p53-dependent senescence in colorectal cancer cells. Mol Cell Biol 25:7758-7769

24. Dhar SK, Tangpong J, Chaiswing L, Oberley TD, St Clair DK (2011) Manganese superoxide dismutase is a p53-regulated gene that switches cancers between early and advanced stages. Cancer Res 71:6684-6695

25. Hussain SP, Amstad P, He P, Robles A, Lupold S, Kaneko I, Ichimiya M, Sengupta S, Mechanic L, Okamura S, Hofseth LJ, Moake M, Nagashima M, Forrester KS, Harris CC (2004) p53induced up-regulation of MnSOD and GPx but not catalase increases oxidative stress and apoptosis. Cancer Res 64:2350-2356

26. Li Z, Shi K, Guan L, Cao T, Jiang Q, Yang Y, Xu C (2010) ROS leads to MnSOD upregulation through ERK2 translocation and p53 activation in selenite-induced apoptosis of NB4 cells. FEBS Lett 584:2291-2297

27. Pani G, Koch OR, Galeotti T (2009) The p53-p66shc-Manganese Superoxide Dismutase (MnSOD) network: a mitochondrial intrigue to generate reactive oxygen species. Int J Biochem Cell Biol 41:1002-1005

28. Pani G, Galeotti T (2011) Role of MnSOD and p66shc in mitochondrial response to p53. Antioxid Redox Signal 15:1715-1727

29. Robbins D, Zhao Y (2012) Oxidative Stress Induced by MnSODp53 Interaction: pro- or Anti-Tumorigenic? J Signal Transduct 2012:101465

30. You S, Kong BW, Jeon SY, Foster DN, Kim H (2004) Deregulation of catalase, not MnSOD, is associated with necrotic death of p53-defective DF-1 cells under antimycin A-induced oxidative stress. Mol Cells 18:220-229

31. Mikstacka R, Rimando AM, Dutkiewicz Z, Stefanski T, Sobiak S (2012) Design, synthesis and evaluation of the inhibitory selectivity of novel trans-resveratrol analogues on human recombinant CYP1A1, CYP1A2 and CYP1B1. Bioorg Med Chem 20:5117-5126

32. Mikstacka R, Baer-Dubowska W, Wieczorek M, Sobiak S (2008) Thiomethylstilbenes as inhibitors of CYP1A1, CYP1A2 and CYP1B1 activities. Mol Nutr Food Res 52(Suppl 1):S77-S83

33. Piver B, Fer M, Vitrac X, Merillon JM, Dreano Y, Berthou F, Lucas D (2004) Involvement of cytochrome P450 1A2 in the biotransformation of trans-resveratrol in human liver microsomes. Biochem Pharmacol 68:773-782

34. Mikstacka R, Przybylska D, Rimando AM, Baer-Dubowska W (2007) Inhibition of human recombinant cytochromes P450 CYP1A1 and CYP1B1 by trans-resveratrol methyl ethers. Mol Nutr Food Res 51:517-524

35. So KS, Oh JE, Han JH, Jung HK, Lee YS, Kim SH, Chun YJ, Kim MY (2008) Induction of apoptosis by a stilbene analog involves Bax translocation regulated by p38 MAPK and Akt. Arch Pharm Res 31:438-444

36. Chun YJ, Oh YK, Kim BJ, Kim D, Kim SS, Choi HK, Kim MY (2009) Potent inhibition of human cytochrome P450 1B1 by tetramethoxystilbene. Toxicol Lett 189:84-89

37. Chun YJ, Lee SK, Kim MY (2005) Modulation of human cytochrome P450 1B1 expression by 2,4,3',5'-tetramethoxystilbene. Drug Metab Dispos 33:1771-1776

38. Murias M, Handler N, Erker T, Pleban K, Ecker G, Saiko P, Szekeres T, Jager W (2004) Resveratrol analogues as selective cyclooxygenase-2 inhibitors: synthesis and structure-activity relationship. Bioorg Med Chem 12:5571-5578

39. Chomczynski P, Sacchi N (1987) Single-step method of RNA isolation by acid guanidinium thiocyanate-phenol-chloroform extraction. Anal Biochem 162:156-159
40. Seibert H, Morchel S, Gulden M (2002) Factors influencing nominal effective concentrations of chemical compounds in vitro: medium protein concentration. Toxicol In Vitro 16:289-297

41. Doherty MM, Michael M (2003) Tumoral drug metabolism: perspectives and therapeutic implications. Curr Drug Metab 4:131-149

42. Michael M, Doherty MM (2005) Tumoral drug metabolism: overview and its implications for cancer therapy. J Clin Oncol 23:205-229

43. Svoboda M, Wlcek K, Taferner B, Hering S, Stieger B, Tong D, Zeillinger R, Thalhammer T, Jager W (2011) Expression of organic anion-transporting polypeptides $1 \mathrm{~B} 1$ and $1 \mathrm{~B} 3$ in ovarian cancer cells: relevance for paclitaxel transport. Biomed Pharmacother 65:417-426

44. Miksits M, Wlcek K, Svoboda M, Thalhammer T, Ellinger I, Stefanzl G, Falany CN, Szekeres T, Jaeger W (2010) Expression of sulfotransferases and sulfatases in human breast cancer: impact on resveratrol metabolism. Cancer Lett 289:237-245

45. Androutsopoulos V, Arroo RR, Hall JF, Surichan S, Potter GA (2008) Antiproliferative and cytostatic effects of the natural product eupatorin on MDA-MB-468 human breast cancer cells due to CYP1-mediated metabolism. Breast Cancer Res 10:R39

46. Piotrowska H, Myszkowski K, Ziolkowska A, Kulcenty K, Wierzchowski M, Kaczmarek M, Murias M, KwiatkowskaBorowczyk E, Jodynis-Liebert J (2012) Resveratrol analogue 3,4,4',5-tetramethoxystilbene inhibits growth, arrests cell cycle and induces apoptosis in ovarian SKOV-3 and A-2780 cancer cells. Toxicol Appl Pharmacol 263:53-60

47. Bendaly J, Metry KJ, Doll MA, Jiang G, States JC, Smith NB, Neale JR, Holloman JL, Pierce WM, Hein DW (2009) Role of human CYP1A1 and NAT2 in 2-amino-1-methyl-6-phenylimidazo[4,5-b]pyridine-induced mutagenicity and DNA adducts. Xenobiotica 39:399-406

48. Martinez VG, O'Connor R, Liang Y, Clynes M (2008) CYP1B1 expression is induced by docetaxel: effect on cell viability and drug resistance. Br J Cancer 98:564-570

49. Liu Y, Bodmer WF (2006) Analysis of P53 mutations and their expression in 56 colorectal cancer cell lines. Proc Natl Acad Sci USA 103:976-981

50. Rodrigues NR, Rowan A, Smith ME, Kerr IB, Bodmer WF, Gannon JV, Lane DP (1990) p53 mutations in colorectal cancer. Proc Natl Acad Sci USA 87:7555-7559

51. Debernardis D, Sire EG, De FP, Vikhanskaya F, Valenti M, Russo P, Parodi S, D'Incalci M, Broggini M (1997) p53 status does not affect sensitivity of human ovarian cancer cell lines to paclitaxel. Cancer Res 57:870-874

52. Wasielewski M, Elstrodt F, Klijn JG, Berns EM, Schutte M (2006) Thirteen new p53 gene mutants identified among 41 human breast cancer cell lines. Breast Cancer Res Treat 99:97-101

53. Gartel AL, Feliciano C, Tyner AL (2003) A new method for determining the status of $\mathrm{p} 53$ in tumor cell lines of different origin. Oncol Res 13:405-408

54. Jia LQ, Osada M, Ishioka C, Gamo M, Ikawa S, Suzuki T, Shimodaira H, Niitani T, Kudo T, Akiyama M, Kimura N, Matsuo M, Mizusawa H, Tanaka N, Koyama H, Namba M, Kanamaru R, Kuroki T (1997) Screening the p53 status of human cell lines using a yeast functional assay. Mol Carcinog 19:243-253

55. Scheffner M, Munger K, Byrne JC, Howley PM (1991) The state of the p53 and retinoblastoma genes in human cervical carcinoma cell lines. Proc Natl Acad Sci USA 88:5523-5527 